\title{
Evaluation of left ventricular functions by conventional echocardiography and tissue Doppler imaging in children with rheumatic mitral regurgitation
}

\author{
Romatizmal mitral yetmezlikli çocuklarda geleneksel \\ ekokardiyografi ve doku Doppler görüntüleme ile \\ sol ventrikül fonksiyonlarının değerlendirilmesi
}

\author{
Abdullah Yazar, ${ }^{1}$ Sevim Kararslan ${ }^{2}$ \\ 'Department of Pediatric Emergency, Necmettin Erbakan University Meram Faculty Faculty of Medicine, Konya, Turkey \\ ${ }^{2}$ Department of Pediatric Cardiology, Necmettin Erbakan University Meram Faculty Faculty of Medicine, Konya, Turkey
}

\begin{abstract}
Introduction: We aimed to evaluate left ventricular functions in children with mitral regurgitation (MR) who were followed up with the diagnosis rheumatic carditis, by using conventional echocardiography and tissue Doppler imaging (TDI) and compare the results with those of healthy control subjects.

Methods: 30 patients who were followed up with the diagnosis of MR due to sequel of rheumatic carditis in our pediatric cardiology clinic and 30 healthy children aged between 5-15 years were included in the study. The patient group was categorized as mild-moderate $M R(n=20)$, and severe MR $(n=10)$. All echocardiographic and Doppler assessments were performed by a single expert pediatric cardiologist, who was blinded to the clinical and laboratory results of the study group.

Results: LV end-diastolic diameters were significantly increased in patient with severe MR compared to controls $(4.62 \pm 0.82 \mathrm{~cm}, 3.92 \pm 0.39 \mathrm{~cm} ; \mathrm{p}=0.008)$. Also LV end-systolic diameters were found significantly increased in patient with severe MR compared to controls $(2.81 \pm 0.51,2.43 \pm 0.25, \mathrm{p}=0.01)$. There was no statistically significant difference between groups in terms of LV ejection fraction and fractional shortening ( $p>0.05)$. Although peak early diastolic myocardial velocity obtained with TDI did not show significantly difference between the groups ( $p>0.05)$, peak atrial systolic velocity measured from the lateral and septal annulus were significantly increased in patients with severe MR when compared with controls and patients with mild--modarete $M R(p<0.001, p=0.001$; respectively).

Discussion and Conclusion: In our study, LV systolic and diastolic functions obtained by conventional echocardiographic measurements, showed no significant difference between the controls and patients with MR. However, deterioration in subclinical LV systolic and diastolic function was detected by TDI the patient group with MR.

Keywords: Left ventricular functions; mitral regurgitation; tissue Doppler
\end{abstract} imaging.
Özet

Amaç: Romatizmal kardit tanısı ile izlenen mitral yetmezlikli çocuklarda sol ventrikül fonksiyonlarını geleneksel ekokardiyografi ve doku Doppler görüntüleme yöntemiyle değerlendirip, sonuçları sağlıkı kontrol grubu ile karşılaştırmayı amaçladık

Gereç ve Yöntem: Pediatrik kardiyoloji kliniğimizde romatizmal kardit sonras mitral yetmezlik tanısı ile izlenen 30 hasta ve 5-15 yaşları arasında 30 sağlıkl çocuk çalışmaya dahil edildi. Hasta grubu hafif-orta dereceli mitral yetmezlik ve ağır mitral yetmezlik olarak sınıflandııılı. Tüm ekokardiyografik ölçümler çaIıșma grubunun klinik ve laboratuvar sonuçlarına kör olan uzman bir pediatrik kardiyolog tarafından yapıldı.

Bulgular: Ağır mitral yetmezlikli hastalarda sol ventrikül diyastol sonu çaplar kontrol grubuna göre anlamlı derecede artış gösterdi $(4.62 \pm 0.82 \mathrm{~cm}, 3.92 \pm 0.39$ $\mathrm{cm} ; \mathrm{p}=0.008$ ). Yine sol ventrikül sistol sonu çaplarında ağır mitral yetmezlikli hastalarda kontrol grubuna göre anlamlı olarak artmış bulundu $(2.81 \pm 0.51$, $2.43 \pm 0.25, p=0.01)$. Ejeksiyon fraksiyonu ve fraksiyonel kısalma açısından gruplar arasında istatistiksel olarak anlamlı fark yoktu ( $p>0.05)$. Doku Doppler görüntüleme yöntemiyle ölçülen erken diyastolik pik miyokard hızı gruplar arasında istatistiksel olarak anlamlı farklılık göstermediği halde ( $p>0.05)$, atriyal pik sistolik hız, ağır mitral yetmezlikli hastalarda, hem kontrol hem de hafif-orta mitral yetmezlikli hastalara göre anlamlı derecede yüksek ölçüldü (sırasıyla $p<0.001$, $\mathrm{p}=0.001$ ).

Sonuç: Çalışmamızda, geleneksel ekokardiyografik ölçümlerle elde edilen sol ventrikül sistolik ve diyastolik fonksiyonları açısından kontrol grubu ile mitral yetmezlikli hasta grupları arasında istatistiksel olarak anlamlı bir farklılık bulunamamıştır. Buna rağmen mitral yetmezlikli hasta grubunda sol ventriküler fonksiyonlardaki subklinik bozulma doku Doppler görüntüleme yöntemiyle saptanmıştır.

Anahtar Sözcükler: sol ventrikül fonksiyonları; mitral yetmezlik; doku Doppler görüntüleme.

Corresponding (IIletişim): Abdullah Yazar, Necmettin Erbakan Üniv. Meram Tıp Fak., Çocuk Acil Bilim Dalı, Konya, Turkey E-mail (E-posta): drabdullahyazar@hotmail.com 
A though the incidence of acute rheumatic fever (ARF) has declined in recent years, it is still a majör cause of cardiovascular morbidity and mortality especially in developing countries. The Jones criteria, which was lastly updated in 2015, has been used as an important guide in ARF since 1944. Carditis, one of the major criteria, is the most important involvement that determines the prognosis of the disease. ${ }^{[1]}$

In rheumatic carditis, all three layers of the heart (endocardium, myocardium, pericardium) are affected at different levels. The most commonly involved site in the heart in the course of the disease is mitral valve, and the first sign is $M R$ (MR). MR can be acute or chronic. In acute MR, left ventricular function suddenly deteriorates, pulmonary edema and consequent severe dyspnoea, orthopnea, and cyanosis occur. Chronic mitral insufficiency is more insidious and may not be detectable for a long time. ${ }^{[2]}$

The importance of echocardiographic evaluation in carditis has been emphasized in the 1992 revision of the Jones criteria. Echocardiographic examination is not only important in the diagnosis of valve insufficiency, but also in assessing left ventricle (LV) functions and following-up of the patients. ${ }^{[3]}$ Several parameters have been proposed to assess LV function in asymptomatic patients with MR, and LV ejection fraction (EF) is the most commonly used. While the assessment of EF depends on afterload, EF remains higher than normal during the compensated phase of chronic MR. When LV dysfunction develops, EF may decrease but remains within normal limits because of the reduced afterload. Left ventricular cavity dimensions and EF are indirect measurements of the intrinsic myocardial function and both reflect the hemodynamic consequences of MR. ${ }^{[4]}$ Therefore, new parameters for early detection of LV dysfunction are needed during follow-up of patients with MR to designate the true time of surgical treatment of the valve before irreversible LV dysfunction occurs. ${ }^{[5,6]}$

Tissue Doppler imaging (TDI) is a method based on the principle of quantitatively assessing myocardial motion during the heart cycle, based on myocardial reflected Doppler signals. It was first described by Iseaz and his colleagues, ${ }^{[7]}$ and was taken into clinical use by Mc Dicken et al. in 1992. ${ }^{[8]}$ LV dysfunction can be measured by TDI using mitral annular velocities which reflect the contraction of longitudinal subendocardial fibers, and is believed to give an estimation of global left ventricular systolic function with high feasibility and reproducibility. ${ }^{[5,9]}$ In this study, we aimed to evaluate LV systolic and diastolic functions in children with MR who were followed up with the diagnosis of rheumatic carditis by using conventional echocardiography and TDI and compare the results with those of healthy controls.

\section{Materials and Method}

\section{Study Population}

30 patients who were followed up with the diagnosis of MR due to sequel of $\mathrm{RC}$ in our pediatric cardiology clinic between
January 2006 and March 2006 and 30 healthy children aged between 5-15 years were included in the study after receiving their informed consent. ARF diagnosis was based on modified Jones criterion (3). The patient group was categorized as mildmoderate MR $(n=20)$, and severe MR $(n=10)$. Four patients with aortic regurgitatiom and one patient who had an abnormal blood pressure range were excluded from the study. The study was approved by the ethics committee of our institution.

\section{Echocardiographic Evaluation}

Echocardiographic investigations were performed using Sonos 5500 (Hewlett-Packard Phillips Co., Holland) with 2.04.0 $\mathrm{MHz}$ transducers. Echocardiograms were recorded on a 1/2-inch VHS videotape. All echocardiographic and Doppler assessments were performed by a single expert pediatric cardiologist, who was blinded to the clinical and laboratory results of the study group. The measurements were obtained during 3 consecutive cardiac cycles and the average values were computed. Conventional echocardiographic evaluation from the parasternal long-axis view included LV end-diastolic diameter (LVEdD) and end-systolic diameter (LVEsD), septal and LV posterior wall thicknesses in diastole (LVPWd) and systole (LVPWs), EF, LV fractional shortening (FS), Interventricular septum diastolic thickness (IVSd), and Interventricular septum systolic thickness (IVSs).

Teichholz's M-mode formula was used to calculate the LV ejection fraction and LV fractional shortening. All data were obtained according to the recommendations of the American Society of Echocardiography. ${ }^{[10]}$ Grade of MR was determined according to the proportion of jet area to the left atrium dimention and the regurgitant fraction. ${ }^{[11]}$ Transmittal flow patterns were obtained by pulsed-wave Doppler echocardiography from the apical 4-chamber view. Peak early velocity $(E)$ and late diastolic velocity $(A)$, the E/A ratio were measured.

Tissue Doppler imaging velocities were obtained at the apical 4-chamber orientation from two locations: the sample volume was positioned on the lateral and septal aspect of mitral valve annulus. Care was taken to minimize the incidence angle between the Doppler beam and the direction of LV longitudinal wall motion. Peak early diastolic myocardial velocity (Em), peak atrial systolic velocity (Am), and peak systolic myocardial velocity ( $\mathrm{Sm}$ ) were measured by this technique. Also, time intervals; isovolumic contraction time (ICT), isovolumic relaxation time (IRT), ventricular ejection time (VET) was determined. The Doppler-derived index of combined systolic and diastolic myocardial performance (Tei index: ICT + IRT / VET) was used to quantify global LV function. ${ }^{[12]}$

\section{Statistical Analysis}

Continuous variables are expressed as mean \pm SD (range). Normality assumptions were assessed before using parametric tests. Mann Whitney $U$ test was used to compare the nonparametric data. Analysis of ANOVA was used to evaluate 
differences of continuous variables among the three groups. A value of $p<0.05$ was used to indicate statistical significance. All statistical analyses were performed by SPSS for Windows, version 16.0 (SPSS Inc, Chicago, USA).

\section{Results}

The clinical and demographic findings of study population are given in Table 1. No significant difference was found between the groups in terms of age, gender, body surface area, systolic/ diastolic blood pressures and heart rate.

In M-mode echocardiographic measurements; LVEdD values were significantly increased in patient with severe MR compared to controls $(4.62 \pm 0.82 \mathrm{~cm}, 3.92 \pm 0.39 \mathrm{~cm} ; \mathrm{p}=0.008)$. Also LVEsD values were found significantly increased in patient with severe MR compared to controls $(2.81 \pm 0.51,2.43 \pm 0.25$, $p=0.01)$. There was no statistically significant difference between groups in terms of EF and FS ( $p>0.05)$. M-mode echocardiographic measurements of study population were given in Table 2.

In Pulsed Doppler echocardiographic measurements; E values were statistically significantly (in both $\mathrm{p}=0.001$ ) increased in patients with severe MR $(134.5 \pm 25 \mathrm{~cm} / \mathrm{Hg})$ when compared with controls $(97.5 \pm 6.07 \mathrm{~cm} / \mathrm{Hg})$, and patients with mild-modarete MR $(99.6 \pm 14.9 \mathrm{~cm} / \mathrm{Hg})$. While A values were statis- tically significantly (in both $\mathrm{p}<0.001$ ) increased in patients with severe MR $(106.9 \pm 30.7 \mathrm{~cm} / \mathrm{Hg})$ compared with controls $(51.8 \pm 4.2 \mathrm{~cm} / \mathrm{Hg})$ and patients with mild--modarete MR $(56.3 \pm 9.2 \mathrm{~cm} / \mathrm{Hg})$, there was no significant difference between controls and patients with mild--modarete MR ( $>>0.05)$. Also rate of $E / A$ were statistically significantly $(p<0.001, p=0.008)$ increased in patients with with severe MR $(1.31 \pm 0.33)$ when compared with controls $(1.89 \pm 0.22)$ and patients with mild-modarete MR (1.78 \pm 0.21$)$ although no difference was found between controls and patients with mild--modarete MR ( $p>0.05)$. Mitral flow measurements with pulsed-wawe Doppler imaging in patients with severe MR and healthy controls are showed in Figure 1.

Although Em values obtained with TDI did not show significantly difference between the groups ( $p>0.05$ ), Am values measured from the lateral and septal annulus were significantly increased in patients with severe MR when compared with controls and patients with mild--modarete $M R(p<0.001$, $p=0.001$; respectively). All findings of study population that were measured by TDI are given in Table 2. Mitral annulus motions from the apical 4-chamber view with tissue Doppler imaging in patients with severe MR and healthy control are expressed in Figure 2.

Table 1. Clinical and demographic data of study population

\begin{tabular}{|c|c|c|c|c|}
\hline & $\begin{array}{l}\text { Patients with healty } \\
\text { control }(n=30)\end{array}$ & $\begin{array}{l}\text { Patients with mild- } \\
\text { modarete } M R(n=20)\end{array}$ & $\begin{array}{c}\text { Patients with } \\
\text { severe } M R(n=10)\end{array}$ & $\mathbf{p}$ \\
\hline Age (year) & $10.73 \pm 2.4$ & $10.7 \pm 2.6$ & $10.4 \pm 2.5$ & $>0.05$ \\
\hline Body surface area $\left(\mathrm{m}^{2}\right)$ & $1.06 \pm 2.6$ & $1.07 \pm 2.7$ & $1.04 \pm 2.4$ & $>0.05$ \\
\hline Systolic/diastolic blood pressure $(\mathrm{mmHg})$ & $85 \pm 10$ & $86 \pm 8$ & $88 \pm 12$ & $>0.05$ \\
\hline
\end{tabular}

Table 2. M-mode echocardiographic measurements of study population

\section{Patients with healty control $(n=30)$ \\ Patients with mild- modarete $M R(n=20)$}

\begin{tabular}{ll}
\hline LVEdD $(\mathrm{cm})$ & $3.92 \pm 0.39$ \\
LVEsD $(\mathrm{cm})$ & $2.43 \pm 0.25$ \\
LWPWd $(\mathrm{cm})$ & $0.58 \pm 0.11$ \\
LVPWs $(\mathrm{cm})$ & $0.95 \pm 0.13$ \\
IVSd $(\mathrm{cm})$ & $0.65 \pm 0.13$ \\
IVSs $(\mathrm{cm})$ & $1.03 \pm 0.16$ \\
EF & $68.2 \pm 3.8$ \\
FS & $38.1 \pm 2.1$
\end{tabular}

$4.31 \pm 0.42$
$2.71 \pm 0.31$
$0.62 \pm 0.09$
$1.03 \pm 0.12$
$0.61 \pm 0.11$
$0.98 \pm 0.12$
$66.6 \pm 4.3$
$37 \pm 3.2$

Patients with severe $M R(n=10)$

$4.62 \pm 0.82$
$2.81 \pm 0.51$
$0.65 \pm 0.12$
$1.03 \pm 0.13$
$0.61 \pm 0.11$
$0.96 \pm 0.11$
$68 \pm 3.9$

$37.9 \pm 3.1$

$\begin{array}{ccc}\mathbf{p}^{1} & \mathbf{p}^{2} & \mathbf{p}^{3} \\ >0.05 & 0.008 & >0.05 \\ >0.05 & 0.01 & >0.05 \\ >0.05 & >0.05 & >0.05 \\ >0.05 & >0.05 & >0.05 \\ >0.05 & >0.05 & >0.05 \\ >0.05 & >0.05 & >0.05 \\ >0.05 & >0.05 & >0.05 \\ >0.05 & >0.05 & >0.05\end{array}$

MR: MR; LVEdD: Left ventricle end-diastolic diameter; LVEsD: Left ventricle end-systolic diameter; LVPWd: Left ventricle posterior wall diastolic thicknesses; LVPWs: Left ventricle posterior wall interventricular systolic thickness; IVSd: Interventricular septum diastolic thickness; IVSs: Interventricular septum systolic thickness; EF: Left ventricle ejection fraction; FS: Left ventricle fractional shortening; $p^{1}: p$ value of comparison between controls and mild-modarete MR $1 ; p^{2}: p$ value of comparison between controls and severe MR; $p^{3}: p$ value of comparison between mild-modarete MR and severe MR. 

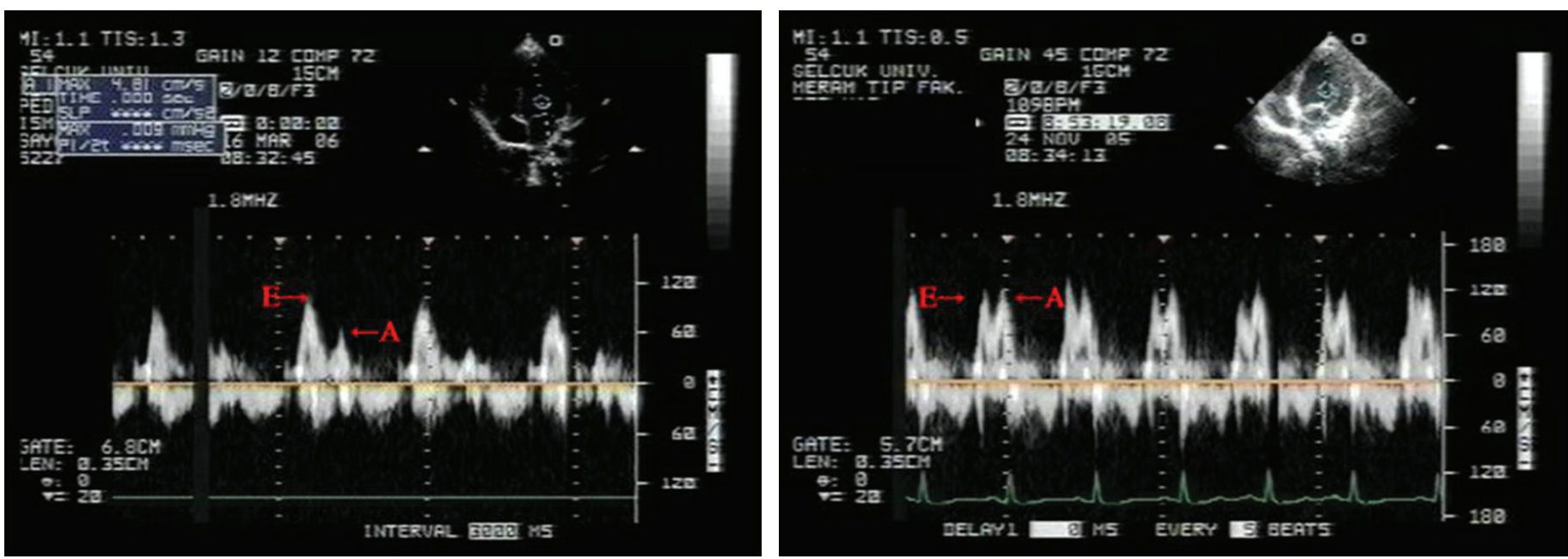

Figure 1. Mitral flow measurements with pulsed-wawe Doppler imaging in patients with severe MR (left) and healthy control (right). E: Early mitral diastolic velocity; A: Late mitral diastolic velocity.
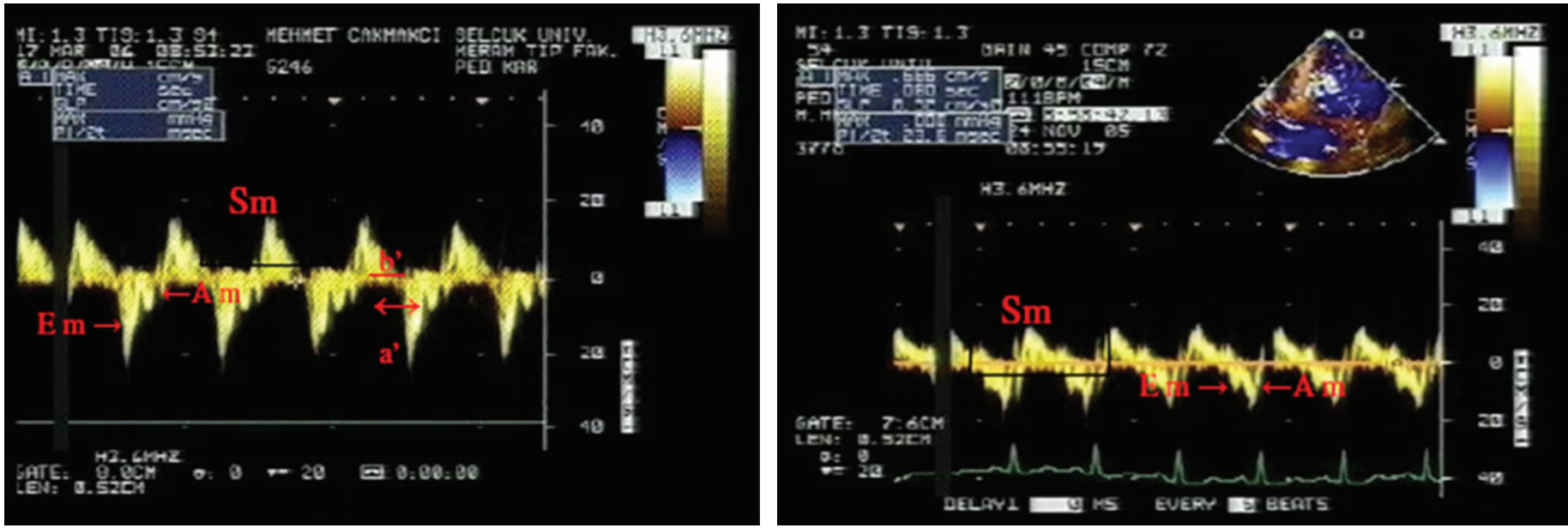

Figure 2. Mitral annulus motions from the apical 4-chamber view with tissue Doppler imaging in patients with severe MR (left) and healthy control (right). Em: Peak early diastolic myocardial velocity; Am: Peak atrial systolic velocity; Sm: Peak systolic myocardial velocity.

\section{Discussion}

In developing countries, rheumatic heart disease continues to be a major public health problem and contributes to significant cardiac morbidity and mortality. Rheumatic carditis results usually in MR in childhood. ${ }^{[13]}$ LV functions in patient with MR may deteriorate over time and may not be detected by classic echocardiographic methods. For this reason new and more effective methods are needed for early diagnosis of ventricular disfunctions. ${ }^{[5]}$ Although in our study no significant difference was foud between patients with rheumatic valvulitis and healthy children in terms of left ventricular functions by conventional echocardiography, TDI revealed LV systolic and diastolic disfunctions in patients with severe MR.

It is known that echocardiographic measurements are influenced by age, gender, heart rate and blood pressure values. [11] There was no significant difference between the groups in terms of these parameters in our study. EF and LVEsD are most commonly used parameters to show left ventricular dysfunc- tion in patients with MR. ${ }^{[10,11]}$ In our study, LVEdD and LVEsD, measured by M-mode, were significantly higher in patients with MR than in healthy controls. While LVEdD was significantly higher in patients with severe MR than in patients with mild-moderate MR, LVEsD values did not show significant difference between the two groups. In addition, EF and FS were measured as normal in all groups and there was no difference between the groups.

The variables obtained from the mitral flow with Doppler are the basis for the evaluation of diastolic function, but are influenced by many physiological factors, especially changes in the filling pressure. E wave, A wave, E wave deceleration time and $A$ wave duration are used to assess mitral flow. ${ }^{[14]}$ While $E$ and $A$ wave velocities did not differ in patients with mild MR when compared to the control group, there was a significant increase in the patients with severe MR when compared with both the control group and patients with mild MR. This finding suggests that diastolic functions deteriorate as the degree of MR progresses. 
Table 3. Tissue Doppler echocardiographic measurements of study population

\begin{tabular}{|c|c|c|c|c|c|c|}
\hline & $\begin{array}{l}\text { Patients with healty } \\
\text { control }(n=30)\end{array}$ & $\begin{array}{l}\text { Patients with mild- } \\
\text { modarete } M R(n=20)\end{array}$ & $\begin{array}{c}\text { Patients with } \\
\text { severe MR }(n=\mid 0)\end{array}$ & $\mathbf{p}^{\prime}$ & $\mathbf{p}^{2}$ & $\mathbf{p}^{3}$ \\
\hline \multicolumn{7}{|l|}{ Lateral annulus } \\
\hline $\operatorname{Am}(\mathrm{cm} / \mathrm{s})$ & $7.1 \pm 0.8$ & $7.55 \pm 1.3$ & $13.9 \pm 3.7$ & $>0.05$ & $<0.001$ & 0.001 \\
\hline $\mathrm{Em} / \mathrm{Am}$ & $2.54 \pm 0.33$ & $2.45 \pm 0.51$ & $1.4 \pm 0.65$ & $>0.05$ & $<0.001$ & $<0.001$ \\
\hline $\mathrm{Sm}(\mathrm{cm} / \mathrm{s})$ & $9.92 \pm 1.7$ & $10.8 \pm 1.6$ & $11.1 \pm 1.6$ & $>0.05$ & 0.01 & $>0.05$ \\
\hline IRTm & $53.4 \pm 7.5$ & $50.8 \pm 7.3$ & $57.6 \pm 8.7$ & $>0.05$ & 0.004 & 0.001 \\
\hline VET & $288.3 \pm 15.5$ & $278.3 \pm 27.5$ & $237.1 \pm 44.6$ & $>0.05$ & 0.001 & 0.002 \\
\hline Tei index & $0.35 \pm 1.65$ & $0.36 \pm 0.14$ & $0.48 \pm 0.16$ & $>0.05$ & 0.002 & 0.006 \\
\hline \multicolumn{7}{|l|}{ Septal annulus } \\
\hline $\operatorname{Em}(\mathrm{cm} / \mathrm{s})$ & $14.1 \pm 1.06$ & $13.7 \pm 1.45$ & $12.3 \pm 2.7$ & $>0.05$ & $>0.05$ & $>0.05$ \\
\hline $\mathrm{ICT}$ & $52.3 \pm 6.3$ & $52.2 \pm 6.6$ & $57.6 \pm 11.2$ & $>0.05$ & 0.001 & 0.001 \\
\hline IRT & $51.4 \pm 6.9$ & $49.9 \pm 6.7$ & $64.3 \pm 12.7$ & $>0.05$ & 0.004 & 0.002 \\
\hline VET & $283.6 \pm 15.6$ & $274.7 \pm 25.6$ & $243.6 \pm 35.8$ & $>0.05$ & 0.002 & 0.01 \\
\hline Tei index & $0.35 \pm 1.4$ & $0.35 \pm 0.19$ & $0.46 \pm 0.12$ & $>0.05$ & $<0.001$ & 0.001 \\
\hline
\end{tabular}

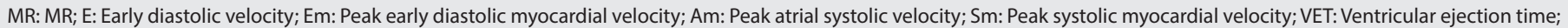

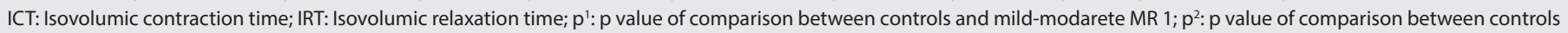
and severe MR; $\mathrm{p}^{3}$ : $\mathrm{p}$ value of comparison between mild-modarete MR and severe MR.

Mitral annular velocity measurements with TDI method are reported to have less preliminary dependence on conventional Doppler values. For this reason, it is suggested that LV long axis functions investigated with TDI method to detect LV function impairment is more sensitive than EF measurement by conventional method and tissue Doppler examination is recommended recently. ${ }^{[15]}$ In the early period of diastolic dysfunction, a decrease in Em and a slight increase in both IRT and Am may be detected by TDI. Em velocity is associated with myocardial relaxation velocity, since it represents early diastolic myocardial conraction. It is accepted that EM is a parameter showing ventricular relaxation independent from volumetric loading. ${ }^{[14,16]}$ In our study, there was a slight decrease in the Em velocities measured from the lateral and septal annulus in patients with severe MR, but there was no difference between the groups. Am velocities obtained from annuli were significantly higher in patients with severe MR compared to both control and patients with mild MR.

The effect of myocardial relaxation on ventricular filling in younger children is more than atrial contraction. Thus, Em is higher than Am and the Em/Am ratio is greater than 1. Em/ Am ratio $>1$ is considered normal and this measurement is not affected by angle and is valid for many wall segments. ${ }^{[17]}$ In our study, the Em / Am ratio in the septal and lateral margins was found to be higher than 1 in all 3 groups and were significantly higher at both annuli in patients severe MR than in the other groups. ICT ve IVT values measured from both annuli were significantly higher in patients with severe MR than controls and patients with mild MR. The IRT is a continuation of the systolic heart cycle, which is dependent on systolic functions in addition to left ventricular relaxation. ${ }^{[15]} \mathrm{IRT}$ is prolonged in patients with impaired relaxation. In our study, IRT values were significantly higher in patients with severe MR compared with controls and patients with mild MR.

Long-acting peak myocardial velocities during the systolic ejection phase are reported to be relatively independent from afterload and reflect left ventricular contractility. In early detection of systolic dysfunction, a reduction in peak systolic myocardial velocities detected on TDI suggested to be useful. ${ }^{[18,19]} \mathrm{Sm}$ velocity in adults being above $5.95 \mathrm{~cm} / \mathrm{s}$ has been reported to have sensitivity and specificity rates of $79 \%$ and $83 \%$, respectively, to distinguish diastolic and systolic heart failure. ${ }^{[20]}$ In our study, Sm velocity measured from septal annulus of the mitral valve was significantly higher in patients with severe MR than in the other groups, but when measured from the lateral annulus it was significantly higher in patients with severe MR only from controls. However, the values for all three groups remained within the normal value limits reported in the literature. ${ }^{[20]}$

The Tei index was first published by Tei and his colleagues in 1995 in a group of patients with cardiomyopathy. Clinical use is fairly easy since this index can easily be obtained by doppler echocardiographic examination and pre-afterload changes are not affected by heart rate and blood pressure changes. 
[12] The Tei index is a sensitive parameter showing the global function of the left ventricle. The normal value of the Tei index for the left ventricle is reported to be $0.30-0.37 . .^{[21]}$ In our study, TEl index was measured at normal limits in patients with mildto-moderate MR and healthy controls, but significantly higher in patients with severe MR than other both groups. In patients with severe chronic MR, the progressive reduction in tissue Doppler velocities without a decrease in EF value is considered to be a stimulating finding indicating that LV systolic functions progressively deteriorate. ${ }^{[17]}$

\section{Study Limitations}

Our study had some limitations, such as small sample size of patients with severe MR, the patients were taking different treatments and novel biomarkers such as BNP and NT-ProBNP levels were not measured.

\section{Conclusion}

In our study, LV systolic and diastolic functions obtained by conventional echocardiographic measurements, showed no significant difference between the controls and patients with rheumatic valve disease. However, deterioration in subclinical LV systolic and diastolic function was detected by TDI the patient group with rheumatic MR. We think that close follow-up of LV functions is important to estimate prognosis in those with severe MR. More prospective work is needed in this topic.

Conflict of interest: There are no relevant conflicts of interest to disclose.

\section{References}

1. Gewitz MH, Baltimore RS, Tani LY, Sable CA, Shulman ST, Carapetis $J$, et al. American Heart Association Committee on Rheumatic Fever, Endocarditis, and Kawasaki Disease of the Council on Cardiovascular Disease in the Young. Revision of the Jones Criteria for the diagnosis of acute rheumatic fever in the era of Doppler echocardiography: a scientific statement from the American Heart Association. Circulation 2015;131:1806-18.

2. Park MK. Pediatric cardiology for Practitioners. 4th ed. San Antorino: Texas; 2002.

3. Fujikawa S. Guidelines for the diagnosis of rheumatic fever: Jones criteria, updated 1992. Ryumachi 1993;33:451-5.

4. Enriquez-Sarano M, Tajik AJ, Schaff HV, Orszulak TA, McGoon MD, Bailey KR, et al. Echocardiographic prediction of left ventricular function after correction of MR: results and clinical implications. J Am Coll Cardiol 1994;24:1536-43.

5. Polat TB, Yalcin Y, Erdem A, Zeybek C, Akdeniz C, Celebi A. Tissue Doppler imaging in rheumatic carditis. Cardiol Young 2014;24:359-65.
6. Nazli C, Kinay O, Ergene O, Yavuz T, Gedikli O, Hoscan Y, et al. Use of tissue Doppler echocardiography in early detection of left ventricular systolic dysfunction in patients with MR. Int J Cardiovasc Imaging 2003;19:199-209.

7. Isaaz K, Thompson A, Ethevenot G, Cloez JL, Brembilla B, Pernot C. Doppler echocardiographic measurement of low velocity motion of the left ventricular posterior wall. Am J Cardiol 1989;64:66-75.

8. Mc Dicken WN, Sutherland GR, Moran CM, Gordon L. Colour Doppler velocity imaging of the myocardium. Ultrasound Med Biol 1992;18:651-4.

9. Agricola E, Galderisi M, Oppizzi M, Schinkel AF, Maisano F, De Bonis $M$, et al. Pulsed tissue Doppler imaging detects early myocardial dysfunction in asymptomatic patients with severe MR. Heart 2004;90:406-10.

10. Sahn DJ, De Maria A, Kisslo J, Weyman A. The committee on Mmode standardization of results of a survey of echocardiographic measurements. Circulation 1978;58:1072-83.

11. Feigenbaum H. Ecocardiyography. 5th ed. India Lea \& Febiger 1994.

12. Tei C, Ling LH, Hodge DO, Bailey KR, Oh JK, Rodeheffer RJ, et al. New index of combined systolic and diastolic myocardial performance: a simple and reproducible measure of cardiac function-a study in normals and dilated cardiomyopathy. J Cardiol 1995;26:357-66.

13. Rocha P, Freitas $S$, Alvares $S$. Rheumatic fever-a review of cases. Rev Port Cardiol 2000;19:921-8.

14. Khouri SJ, Maly GT, Suh DD, Walsh TE. A practical approach to the echocardiographic evaluation of diastolic function. J Am Soc Echocardiogr 2004;17:290-7.

15. Bruch C, Gradaus R, Gunia S, Breithardt G, Wichter T. Doppler tissue analysis of annular velocities: Evidence for systolic abnormalities in patients with diastolic heart failure. J Am Soc Echocardiogr 2003;16:1031-6.

16. Marwick TH. Clinical applications of tissue Doppler imaging: a promise fulfilled. Heart 2003;89:1377-78.

17. De Boeck BW, Cramer MJ, Oh JK, van der Aa RP, Jaarsma W. Spectral pulsed tissue Doppler imaging in diastole: $A$ tool to increase our insight in and assessment of diastolic relaxation of the left ventricle. Am Heart J 2003;146:411-9.

18. Nazli C, Kinay O, Ergene O, Yavuz T, Gedikli O, Hoscan Y, et al. Use of tissue Doppler echocardiography in early detection of left ventricular systolic dysfunction in patients with mitral regurgitation. Int J Cardiovasc Imaging 2003;19:199-209.

19. Marwick TH. Clinical applications of tissue Doppler imaging: a promise fulfilled. Heart 2003;89:1377-8.

20. Eidem BW, McMahon CJ, Cohen RR, Wu J, Finkelshteyn I, Kovalchin JP, et al. Impact of cardiac growth on Doppler tissue imaging velocities: a study in healthy children. J Am Soc Echocardiogr 2004; 17:212-21.

21. McMahon CJ, Nagueh SF, Pignatelli RH, Denfield SW, Dreyer WJ, Price JF, et al. Chateterization of left ventricular diastolic function by tissue Doppler imaging and clinical statusin children with hypertrophic cardiomyopathy. Circulation 2004;109:1756-62. 